\title{
Activity of superoxide dismutase obtained from senile cataract lens - effect of diabetes mellitus ${ }^{\star}$
}

\author{
Tomasz Panz ${ }^{1 \bowtie}$, Rafał Wójcik ${ }^{1 *}$ and Krystyna Krukar-Baster ${ }^{2^{\star}}$ \\ ${ }^{1} J a g i e l l o n i a n$ University, Faculty of Biochemistry, Biophysics and Biotechnology, Kraków, Poland; \\ ${ }^{2}$ Collegium Medicum of the Jagiellonian University, Ophthalmology Clinic, Kraków, Poland
}

Received: 27 April, 2008; revised: 04 December, 2008; 05 December, 2008 available on-line: 18 December, 2008

\begin{abstract}
The activity of $\mathrm{Cu}, \mathrm{Zn}$ superoxide dismutase in the fluid obtained from eye lens capsules after cataract surgery was investigated in samples obtained from patients with senile cataract and with senile cataract combined with diabetes mellitus. Two parameters were measured and compared: the frequency of occurrence of detected superoxide dismutase activity and the relative activity of the enzyme in samples derived from senile cataract patients versus those from the patiens affected additionally by diabetes mellitus. It was confirmed that the decrease of superoxide dismutase activity during cataract was additionally promoted by diabetes mellitus.
\end{abstract}

Keywords: $\mathrm{Cu}, \mathrm{Zn}$ superoxide dismutase activity, senile cataract, diabetes mellitus

\section{INTRODUCTION}

A number of hypotheses concerning the etiology of cataract have been put forward (Francis et al., 1999; Harding 2002). Most of them assume an involvement of reactive oxygen species in the primary stages of the pathology (Taylor, 1995). Therefore, studies of the defense mechanisms against reactive oxygen species and the status of defense systems during cataract might shed light on specific pathways of the cataract-associated degeneration. One of the key anti-oxidative enzymes present in the eye lens is $\mathrm{Cu}, \mathrm{Zn}$ superoxide dismutase $(\mathrm{Cu}, \mathrm{Zn}$-SOD) (Behndig et al., 1998) localized mainly in the cytosol of differentiated eye lens cells, forming inside the lens extremely elongated fibers without nuclei and mitochondria. Due to the lack of these organelles, the only source of the enzyme present in the eye lens fluid is the cytosol. The $\mathrm{Cu}, \mathrm{Zn}$ superoxide dis- mutase is relatively resistant to various stress conditions. Due to this feature it can be studied more readily than other enzymes as cataract progresses, because in most cases the enzyme retains partial activity in primary stages of cataract formation.

\section{MATERIALS AND METHODS}

The material was obtained from the Ophthalmology Clinic; it was the fluid remaining after flushing of the interior of the lens capsule after surgical removal of cataract nucleus by nucleus expulsion. There were 73 samples of senile cataract collected over a period of three months. For each sample collected, additional medical information about the patient was provided. After collection the fluid was frozen and kept at $-20^{\circ} \mathrm{C}$ until the measurements. The salts used for buffer preparation

\footnotetext{
$\triangle$ Corresponding author: Tomasz Panz, Jagiellonian University, Faculty of Biochemistry, Biophysics and Biotechnology, Gronostajowa 7, 30-387 Kraków, Poland; phone: (48) 12664 6514; fax: (48) 12664 6902; e-mail: tomek.panz@gmail.com

^ The results were presented as a poster at the 35th Winter School of the Jagiellonian University Faculty of Biochemistry, Biophysics and Biotechnology, Zakopane, Poland, February 2008.

* Present address: Ośrodek Ekspertyz Medycznych Aestimo s.c., ul. Majora 5B/18, 31-422 Kraków, Poland

"Present addres: Szpital Specjalistyczny im. Stefana Żeromskiego, os. Na Skarpie 66, 31-913 Kraków, Poland

Abbreviations: Cu,Zn-SOD, SOD, superoxide dismutase.
} 
were purchased at POCh (Gliwice, Poland). Adrenaline was purchased from Sigma-Aldrich (Milwaukee, USA). The Folin reagent used for protein determination was from Merck (Germany). Before measurements the fluid was thawed, thoroughly mixed and divided into small aliquots suitable for measurements of protein content and enzyme activity. The protein content was measured by the Lowry method (Lowry et al., 1951). The superoxide dismutase activity was measured by the adrenalin method (Misra, 1985). Briefly, $100 \mu$ of sample was diluted in $2.8 \mathrm{ml}$ of carbonate buffer, $\mathrm{pH} \mathrm{10.2,} \mathrm{in-}$ cubated at $30^{\circ} \mathrm{C}$ and placed into $1 \mathrm{~cm}$ quartz spectrophotometer cuvette. The reaction was started by adding $100 \mu \mathrm{l}$ of $10 \mathrm{mM}$ adrenalin solution in $10 \mathrm{mM} \mathrm{HCl}$. In the basic $\mathrm{pH}$ the adrenalin was spontaneously oxidized, with the kinetics recorded by measuring the increase of absorbance at $480 \mathrm{~nm}$ over time. The kinetics of adrenalin oxidation in the presence of the sample was compared with the oxidation rate of adrenalin alone. The activity of $\mathrm{Cu}, \mathrm{Zn}$-SOD was calculated as the inhibition of the rate of adrenalin oxidation. The relative activity of SOD was calculated by normalization to the protein content in the sample. The statistical significance of the differences in enzyme activity determination was checked by Student's unpaired $t$-test.

\section{RESULTS AND DISCUSSION}

The samples were assigned to the following independent pairs of categories: primary stages of the cataract (average age of patients $70.5 \pm 9.5$ years, $\mathrm{n}=25$ ) versus mature stages of cataract (average age of patients $69.4 \pm 11.3$ years, $n=48$ ), and samples from patients without diabetes mellitus versus those obtained from diabetes mellitus patients.

Figure 1 shows the occurrence of measurable $\mathrm{Cu}, \mathrm{Zn}$-SOD activity in primary stages of cataract versus frequency of this enzyme activity at mature stages of cataract. It can be seen, that samples with non-detectable activity of $\mathrm{Cu}, \mathrm{Zn}-\mathrm{SOD}$ are substantially more frequent in mature cataract.

There is a tendency of earlier impairment of $\mathrm{Cu}, \mathrm{Zn}-\mathrm{SOD}$ when cataract occurs together with diabetes mellitus, as shown in Fig. 2A. The average age of patients with primary stages of cataract without diabetes mellitus was $68.4 \pm 9.8$ years $(n=12)$, while the average age of patients with primary stages of cataract and with diabetes mellitus was $73.4 \pm 8.7$ years $(n=7)$.

As the cataract proceeds, the difference between the $\mathrm{Cu}, \mathrm{Zn}$-SOD activities in samples derived from cataract patients without and with diabetes mellitus disappears (Fig. 2B). The average age of patients with advance stages of cataract without diabetes mellitus was $69.7 \pm 10.6$ years $(n=36)$ and that of patients with advanced stages of cataract and with diabetes mellitus was $70.9 \pm 12.5$ years $(n=12)$. In both Fig. 1. and Fig. 2. variation within the groups is quite high, indicating difficulties in data interpretation. Table 1 shows data about circulatory pathologies in cataract patients from basic the two categories defined above.

Table 1.

\begin{tabular}{ll}
\hline $\begin{array}{l}\text { Percentage of circulatory system pathologies } \\
\text { in cataract patients }\end{array}$ & $(\mathrm{n}=73)$ \\
\hline Senile cataract without diabetes mellitus & $\begin{array}{l}72.5 \% \\
(\mathrm{n}=54)\end{array}$ \\
\multirow{2}{*}{ Senile cataract with diabetes mellitus } & $\begin{array}{l}84.2 \% \\
(\mathrm{n}=19)\end{array}$ \\
\hline
\end{tabular}

It can be seen that the occurrence of circulatory system diseases among cataract patients is substantially higher in patients with diabetes mellitus.

Further assays of clinical material obtained from cataract patients with diverse medical record and treated by other methods of cataract surgery
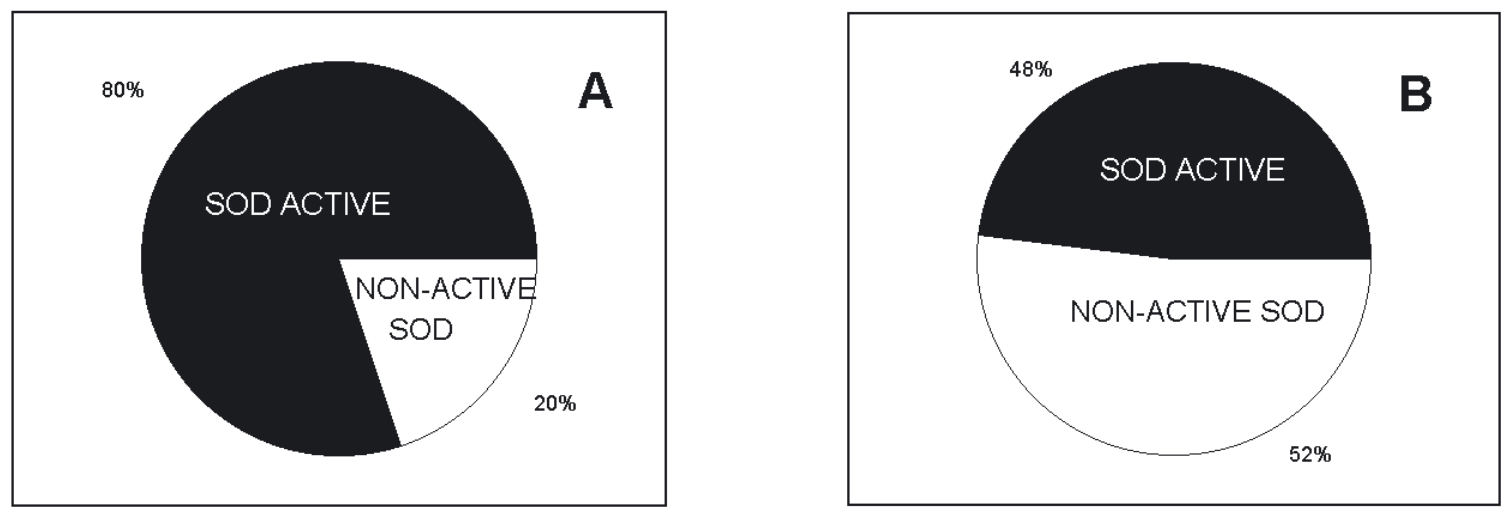

Figure 1. Occurrence of $\mathrm{Cu}, \mathrm{Zn}$ superoxide dismutase activity in different stages of senile cataract.

A. Occurrence of $\mathrm{Cu}, \mathrm{Zn}-\mathrm{SOD}$ activity in primary stages of cataract $(\mathrm{n}=19)$; B. Occurrence of $\mathrm{Cu}, \mathrm{Zn}-\mathrm{SOD}$ activity in mature stages of cataract $(n=54)$. 

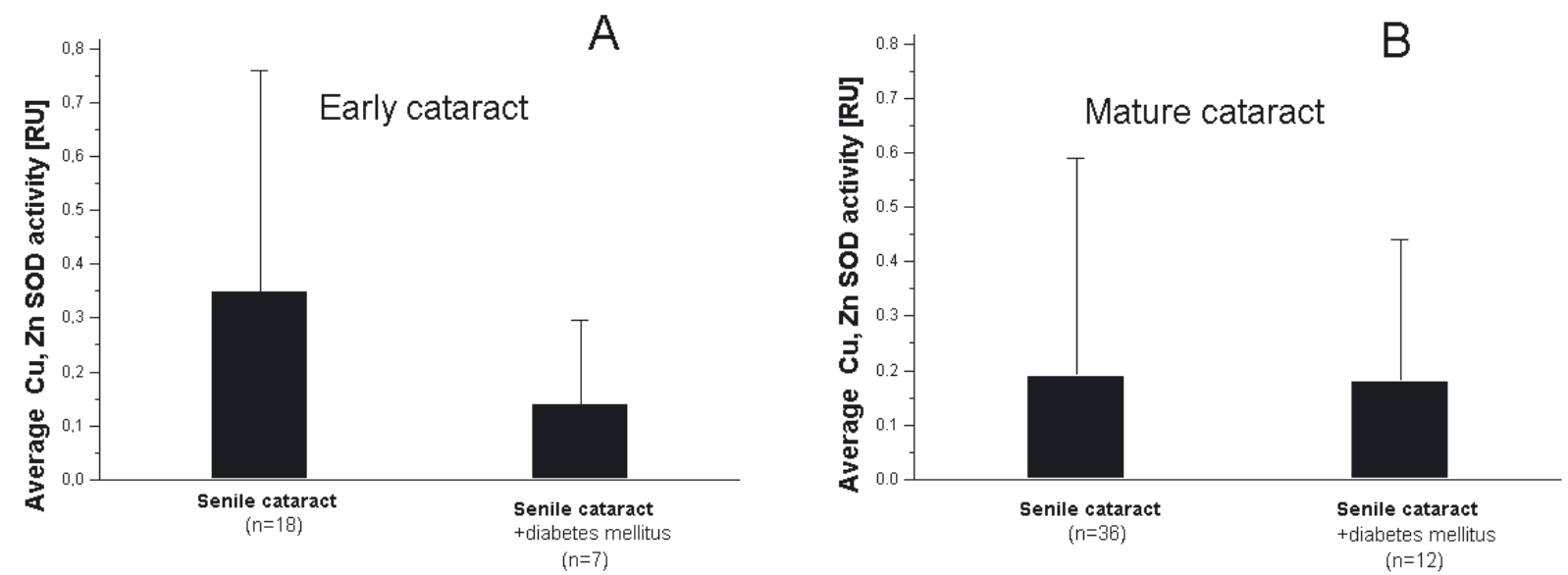

Figure 2. Average Cu,Zn-SOD activity in senile cataract from patients without and with diabetes mellitus. A. Activity of $\mathrm{Cu}, \mathrm{Zn}-\mathrm{SOD}$ in primary stages of cataract; B. Activity of $\mathrm{Cu}, \mathrm{Zn}$-SOD in mature stages of cataract.

are necessary for determination of weak points of antioxidant defense in cataract of diverse etiology.

\section{Acknowledgements}

The authors are very grateful to the medical personnel of the Ophthalmology Clinic for excellent technical help in collecting the samples used for the study.

\section{REFERENCES}

Behndig A, Svensson B, Marklund SL, Karlsson K (1998) Invest Ophth Vis Sci 39: 471-475.
Duncan G, Wormstone M, Davies PD (1997) Brit J Ophtalmol 81: 818-823.

Francis PJ, Berry J, Moore AT, Bhattacharya S (1999) Trends Gen 15: 191-196.

Harding JJ (2002) Ageing Res Rev 1: 465-479.

Lowry CH, Rosenbrough NJ, Farr L, Randall RJ (1951) J Biol Chem 193: 265-275.

Misra HP (1985) In CRC handbook of methods for oxygen radical research. Greenwald RA, ed. CRC Press Boca Raton.

Özmen B, Özmen D, Erkin E, Güner İ, Habif S, Baındır (2002) Clin Biochem 35: 69-82.

Taylor A, Jacques PF, Epstein EM (1995) Am J Clin Nutr 62 (Suppl): 1439S-1447S. 